\title{
The response of surface ozone to climate change over the Eastern United States
}

\author{
P. N. Racherla ${ }^{1}$ and P. J. Adams ${ }^{2}$ \\ ${ }^{1}$ Department of Engineering and Public Policy, Carnegie Mellon University, Pittsburgh, PA, USA \\ ${ }^{2}$ Department of Civil and Environmental Engineering, and Engineering and Public Policy, Carnegie Mellon University, \\ Pittsburgh, PA, USA
}

Received: 18 June 2007 - Published in Atmos. Chem. Phys. Discuss.: 9 July 2007

Revised: 20 December 2007 - Accepted: 22 January 2008 - Published: 22 February 2008

\begin{abstract}
We investigate the response of surface ozone $\left(\mathrm{O}_{3}\right)$ to future climate change in the eastern United States by performing simulations corresponding to present (1990s) and future (2050s) climates using an integrated model of global climate, tropospheric gas-phase chemistry, and aerosols. A future climate has been imposed using ocean boundary conditions corresponding to the IPCC SRES A2 scenario for the 2050s decade. Present-day anthropogenic emissions and $\mathrm{CO}_{2} / \mathrm{CH}_{4}$ mixing ratios have been used in both simulations while climate-sensitive emissions were allowed to vary with the simulated climate. The severity and frequency of $\mathrm{O}_{3}$ episodes in the eastern U.S. increased due to future climate change, primarily as a result of increased $\mathrm{O}_{3}$ chemical production. The 95 th percentile $\mathrm{O}_{3}$ mixing ratio increased by 5 ppbv and the largest frequency increase occured in the 8090 ppbv range; the US EPA's current 8-h ozone primary standard is $80 \mathrm{ppbv}$. The increased $\mathrm{O}_{3}$ chemical production is due to increases in: 1) natural isoprene emissions; 2) hydroperoxy radical concentrations resulting from increased water vapor concentrations; and, 3) $\mathrm{NO}_{\mathrm{x}}$ concentrations resulting from reduced PAN. The most substantial and statistically significant $(p<0.05)$ increases in episode frequency occurred over the southeast and midatlantic U.S., largely as a result of 20\% higher annual-average natural isoprene emissions. These results suggest a lengthening of the $\mathrm{O}_{3}$ season over the eastern U.S. in a future climate to include late spring and early fall months. Increased chemical production and shorter average lifetime are two consistent features of the seasonal response of surface $\mathrm{O}_{3}$, with increased dry deposition loss rates contributing most to the reduced lifetime in all seasons except summer. Significant interannual variability is observed in the frequency of $\mathrm{O}_{3}$ episodes and we find that it is necessary to utilize 5 years or more of simulation data
\end{abstract}

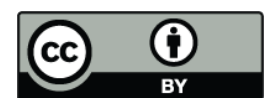

Correspondence to: P. N. Racherla (pavanracherla@cmu.edu) in order to separate the effects of interannual variability and climate change on $\mathrm{O}_{3}$ episodes in the eastern United States.

\section{Introduction}

The reduction of surface ozone, which is harmful to human, animal, and plant health, is an important objective of air quality policy for many governments. Surface ozone is produced through a complex set of photochemical reactions involving $\mathrm{NO}_{\mathrm{x}}\left(=\mathrm{NO}+\mathrm{NO}_{2}\right)$ and volatile organic compounds (VOCs). $\mathrm{NO}_{\mathrm{x}}$ and VOCs are emitted from anthropogenic sources such as fossil fuel power plants, industrial activities and transportation, as well as natural sources such as lightning and soil $\left(\mathrm{NO}_{\mathrm{x}}\right)$, and vegetation (biogenic VOCs such as isoprene). The resulting ozone concentrations depend sensitively upon meterological parameters such as temperature, cloudiness, sunlight, wind speeds and the mixed layer depth. Therefore, changes in these meteorological parameters due to climate change will necessarily impact surface ozone concentrations. However, the direction of change itself is often unclear because of multiple competing effects.

A major conclusion of many previous global modeling studies (Brasseur et al., 1998; Stevenson et al., 2000; Zeng and Pyle, 2003; Liao et al., 2006; Racherla and Adams, 2006), which have assessed the effect of future climate change on global tropospheric ozone is that the global average burden of ozone decreases because of the increased destruction of ozone due to increased water vapor concentrations. In these studies, although ozone chemical production increases it is dominated by the increased destruction of ozone on a global scale in the absence of changes in emissions. On the other hand, Collins et al. (2003); Zeng and Pyle (2003) suggest that the stratosphere-troposphere exchange of ozone is likely to increase due to climate change, which increases tropospheric ozone. Hauglustaine et al. (2005) predict an increase in the upper tropospheric ozone

Published by Copernicus Publications on behalf of the European Geosciences Union. 
concentrations due to climate change, which is primarily due to increased lightning $\mathrm{NO}_{\mathrm{x}}$ caused by more intense convective activity.

While a number of previous modeling studies (Sillman and Samson, 1995; Aw and Kleeman, 2003; Baertsch-Ritter et al., 2004; Dawson et al., 2007) have focused on the effect of individual meteorological parameters on surface ozone, only a few studies have assessed holistically the effect of future climate change. One major conclusion of the former kind of modeling studies is that ozone increases with temperature in both urban and polluted rural environments, with the increase driven largely by a decrease in the formation of peroxyacetyl nitrate (PAN), thereby increasing $\mathrm{NO}_{\mathrm{x}}$ concentrations. Hogrefe et al. (2004) used a regional air quality model centered over the eastern United States to evaluate climate change (IPCC SRES A2 scenario) impacts on air quality and found that increases of up to $5 \mathrm{ppbv}$ are likely in the summertime average daily maximum 8-h ozone concentrations by the 2080s. Murazaki and Hess (2006) used a global chemical transport model model (CTM) driven by future meteorology and present-day emissions (IPCC SRES A1 scenario 2090s) and found that the increased $\mathrm{NO}_{\mathrm{x}}$ concentrations, resulting from reduced PAN in a warmer climate, predominantly affected surface ozone production in polluted regions. This is because increased water vapor concentrations, as a result of climate change, are expected to increase net ozone production in regions with high $\mathrm{NO}_{\mathrm{x}}$ through the reaction $\mathrm{NO}+\mathrm{HO}_{2} \rightarrow \mathrm{NO}_{2}+\mathrm{OH}$, but to decrease net ozone production in regions with low $\mathrm{NO}_{\mathrm{x}}$ through the competing ozone sink $\mathrm{O}_{3}+\mathrm{HO}_{2} \rightarrow 2 \mathrm{O}_{2}+\mathrm{OH}$. Hauglustaine et al. (2005) and Liao et al. (2006) emphasize the potentially important effect of increased biogenic VOC emissions due to future climate change (A2 scenario 2090s) on surface ozone levels; based on their sensitivity studies, performed with a global model, they report that increased natural isoprene emissions account for $30-50 \%$ of the predicted summertime increases in future surface ozone levels over polluted regions such as the eastern United States, western Europe, and northern China.

Only a few modeling studies (Mickley et al., 2004; Hogrefe et al., 2004; Murazaki and Hess, 2006) have examined the effect of future climate change on regional air pollution over the United States. A feature of climate change that emerges from these studies is a decrease in the frequency and intensity of synoptic frontal passages ventilating the boundary layer over the United States. The effect of these changes on future surface ozone levels is not very well understood, however, as it is complicated by simultaneous changes in other processes such as the precursor chemistry, boundary layer mixing, and convection. Nevertheless, all of the above mentioned modeling studies find an increase in the frequency and severity of future air pollution episodes.

Previous global and regional modeling studies that have examined the response of surface ozone to future climate change at regional scales, although relevant, suffer from one or more of the following limitations: (1) neglect climate change impacts outside their domain due to their assumption of constant boundary conditions (BCs); (2) do not consider the climate-sensitivity of ozone precursor emissions such as isoprene; and, (3) do not examine the seasonality of the ozone response, as they focus on summertime ozone.

The objective of this study is to examine the seasonal and regional response of surface ozone to future climate change, with a focus on the eastern United States. Anthropogenic emissions are held constant between present and future simulations, but the model allows climate-sensitive biogenic emissions to vary with future climate. We consider a climate change scenario (IPCC SRES A2) corresponding to the 2050s. We examine the effects of climate change on the severity and frequency of ozone episodes, surface layer ozone budget, and the length of the ozone season. We also examine the effect of interannual variability vis-a-vis the predicted impacts due to climate change. Details of the model, the simulations performed, and the predicted climate change over the eastern United States are provided in Sect. 2. The results are presented and discussed in Sect. 3. Finally, we present our conclusions in Sect. 4.

\section{Methods}

\subsection{Model overview}

We utilize a "unified" global model (Liao et al., 2003, 2004) of climate, photochemistry, and aerosols consisting of: (1) the Goddard Institute for Space Studies general circulation model II' (GISS GCM II') (Hansen et al., 1983; Rind and Lerner, 1996; Rind et al., 1999); (2) the Harvard tropospheric $\mathrm{O}_{3}-\mathrm{NO}_{\mathrm{x}}$-hydrocarbon chemical model (Mickley et al., 1999); and, (3) an aerosol model including sulfate, nitrate, ammonium, black carbon, and organic carbon (Adams et al., 1999; Chung and Seinfeld, 2002; Liao et al., 2003, 2004).

The version of GISS GCM II' incorporated in the current study is an atmosphere only GCM. It has a horizontal resolution of $4^{\circ}$ latitude by $5^{\circ}$ longitude, with nine vertical layers centered at 959, 894, 786, 634, 468, 321, 201, 103, and $26 \mathrm{hPa}$. The model uses specified monthly mean ocean boundary conditions in the form of sea surface temperatures (SSTs), sea-ice coverage and sea-ice mass. The dynamical time step of the GCM is $1 \mathrm{~h}$. Necessary GCM variables are passed to the tropospheric gas-phase chemistry and aerosol modules every $4 \mathrm{~h}$.

The model transports 88 species; of these, 24 species are used to describe $\mathrm{O}_{3}-\mathrm{NO}_{\mathrm{x}}$-hydrocarbon chemistry; the remainder are for the simulation of the aerosols. The model is constrained in the stratosphere by applying flux upper boundary conditions between the seventh and eighth model layers (approximately $150 \mathrm{hPa}$ ) to represent transport across the tropopause (Wang et al., 1998; Mickley et al., 1999). 
The flux upper boundary conditions for ozone is based on the observed latitudinally and seasonally dependent crosstropopause air mass fluxes (Appenzeller et al., 1996), along with ozonesonde measurements at $100 \mathrm{hPa}$ (Logan, 1999). In the current study, a stratospheric ozone flux of $400 \mathrm{Tg}^{-1}$, which was used in the previous model versions (Liao et al., 2003), is specified. We use this value in both present and future climate simulations discussed in Sect. 2.4.

The dry deposition of all gas-phase species is determined based on the resistance-in-series scheme of Wesely (1989), wherein the dry deposition velocity is inversely proportional to the sum of the aerodynamic, quasi-laminar sublayer and surface resistances (Wang et al., 1998). The aerodynamic and quasi-laminar sublayer resistances are calculated based on the GCM surface fluxes of momentum and heat while the surface resistance is a function of the surface type and the species. Wet deposition is coupled with the GCM treatment of clouds and precipitation (Koch et al., 1999; Del Genio and Yao, 1993; Del Genio et al., 1996).

\subsection{Isoprene chemistry}

Pertinent to this study is the model's isoprene oxidation mechanism, the details of which are provided in Horowitz et al. (1998) and references therein. The primary oxidation pathways for isoprene are the reactions with $\mathrm{OH}, \mathrm{O}_{3}$, and $\mathrm{NO}_{3}$. The reaction with $\mathrm{OH}$ is the dominant sink, and it produces a variety of peroxy radicals (lumped together as $\mathrm{RIO}_{2}$ ). The principal branch of the $\mathrm{NO}+\mathrm{RIO}_{2}$ reaction produces $\mathrm{HO}_{2}$, methacrolein, methylvinyl ketone, formaldehyde, and other carbonyl compounds. Of particular importance is the model's treatment of the secondary branch of $\mathrm{NO}+\mathrm{RIO}_{2}$, which produces isoprene nitrates, with an assumed yield of $12 \%$. The model assumes that the isoprene nitrates react rapidly with $\mathrm{OH}$ and $\mathrm{O}_{3}$ and return $\mathrm{NO}_{\mathrm{x}}$ to the atmosphere with $100 \%$ efficiency.

The model's assumption of $100 \%$ recycling of isoprene nitrates to $\mathrm{NO}_{\mathrm{x}}$ is quite uncertain as some field studies have suggested that the isoprene nitrates are likely to deposit quickly, i.e., on a timescale comparable to $\mathrm{HNO}_{3}$ deposition, thereby removing $\mathrm{NO}_{\mathrm{x}}$ from the atmosphere (Giacopelli et al., 2005). However, a more recent modelingobservational analysis by Horowitz et al. (2007) suggests that atmospheric observations of total organic nitrates were best supported when an isoprene nitrate yield of 4 to $8 \%$ and $40 \%$ recycling of isoprene nitrates to $\mathrm{NO}_{\mathrm{x}}$ was assumed.

\subsection{Emissions}

The anthropogenic emissions used in the model are summarized in Liao et al. $(2003,2004)$. These emissions correspond to the present-day; we utilize them in both present and future climate simulations discussed in Sect. 2.4. Climatesensitive ozone precursor emissions include isoprene, biogenic lumped $\geq \mathrm{C}_{3}$ alkenes, biogenic acetone, lightning $\mathrm{NO}_{\mathrm{x}}$, and soil $\mathrm{NO}_{\mathrm{x}}$. The model, however, does not consider the climate-sensitivity of emissions of reactive hydrocarbons with potential for aerosol formation, which include monoterpenes and sesquiterpenes. The model assumes a static vegetation distribution and corresponding base isoprene emissions from the Global Emission Inventory Activity (GEIA) (Guenther et al., 1995). The isoprene emitted in a model grid cell and a time step is a function of the leaf area, and the GCM provided 4-hourly values of temperature and solar radiation (Guenther et al., 1995; Wang et al., 1998). Biogenic emissions of lumped $\geq C_{3}$ alkenes and acetone are estimated by scaling to isoprene emissions (Goldstein et al., 1996; Singh et al., 1994). The emission ratios per atom $\mathrm{C}$ isoprene are 0.051 atoms $\mathrm{C}$ for lumped $\geq \mathrm{C}_{3}$ alkenes and 0.015 molecules for acetone. The parameterizations for lightning $\mathrm{NO}_{\mathrm{x}}$ and soil $\mathrm{NO}_{\mathrm{x}}$ emissions are provided in Wang et al. (1998); the meteorological parameters that influence their emissions are the frequency of convective events, and temperature and precipitation, respectively. Therefore, the model treats the climate sensitivity of these emissions such that the emissions rates of these species change between the present and future climate simulations discussed in Sect. 2.4.

\subsection{Simulations}

Two simulations, each of ten and a half years duration, were performed with the first six months ignored to allow for model initialization. The first simulation corresponds to present climate (1990s) while the second simulation corresponds to a future climate (IPCC SRES A2 scenario 2050s). Hereafter, we refer to these simulations as present and future climate simulations, and abbreviate them as PC simulation and FC simulation, respectively. Present-day anthropogenic emissions were used in both simulations while natural climate-sensitive emissions were allowed to vary with the simulated climate (see Sect. 2.3).

A present-day $\mathrm{CO}_{2}$ mixing ratio of $370 \mathrm{ppmv}$ and 1.7 ppmv for $\mathrm{CH}_{4}$ was specified in both simulations. Future climate is imposed by changing the ocean boundary conditions that drive the GCM. This alternate approach to simulating climate change is attractive because it avoids the large amounts of computer time that would be required to simulate the dynamics and transient response of the ocean, if a greenhouse gas forcing were imposed on the system (Cess et al., 1990). The ocean boundary conditions used in this study are obtained from separate transient climate simulations performed using a fully coupled atmosphere-ocean GCM (the GISS Model III Russell et al., 1995, R. Healy, personal communication), with greenhouse gas and sulfate/carbonaceous aerosol radiative forcings from the IPCC SRES A2 scenario. Details of these transient climate simulations are provided in Robertson et al. (2001). We use the decadally averaged ocean boundary conditions (1990s/2050s) from the above transient climate simulation, with month-to-month variability. 
Table 1. The average value (May-Sep) for key climate variables in the surface layer (984-934 hPa) of Southeast and Midtlantic (95-65 $\mathrm{W}$ and $24-40^{\circ} \mathrm{N}$ ) and Northeast (95-65 ${ }^{\circ} \mathrm{W}$ and $\left.40-48^{\circ} \mathrm{N}\right)$ United States for the present climate (PC) and future climate (FC) simulations; the last column shows the percent difference, i.e., (FC-PC)/PC, for each variable.

\begin{tabular}{lrrc}
\hline & PC & FC & Difference (=(FC-PC)/PC) \\
\hline Southeast and Midtlantic USA & & & \\
$\quad$ Air temperature $\left({ }^{\circ} \mathrm{C}\right)$ & 21.9 & 23.5 & $7.3 \%$ \\
Total cloud cover $(\%)$ & 59.4 & 58.2 & $-2.0 \%$ \\
Wind speed $\left(\mathrm{m} \mathrm{s}^{-1}\right)$ & 4.5 & 4.7 & $4.5 \%$ \\
Absolute humidity $\left(10^{-4} \mathrm{~kg} \mathrm{H}_{2} \mathrm{O} / \mathrm{kg}\right.$ air $)$ & 126.0 & 137.0 & $8.8 \%$ \\
Northeast USA & & & \\
Air temperature $\left({ }^{\circ} \mathrm{C}\right)$ & 15.9 & 17.6 & $10.7 \%$ \\
Total cloud cover $(\%)$ & 67.8 & 66.1 & $-2.5 \%$ \\
$\quad$ Wind speed (m s $\left.{ }^{-1}\right)$ & 4.4 & 4.5 & $2.3 \%$ \\
Absolute humidity $\left(10^{-4} \mathrm{~kg} \mathrm{H}_{2} \mathrm{O} / \mathrm{kg}\right.$ air $)$ & 94.2 & 104.0 & $10.4 \%$ \\
\hline
\end{tabular}

For the analyses on the severity and frequency of ozone episodes (definition provided below), we utilize 4-h average surface ozone mixing ratios, 10 simulation years worth, saved over the eastern United States $\left(105-65^{\circ} \mathrm{W}\right.$ and 24 $48^{\circ} \mathrm{N}$ ), corresponding to 37 model grid cells in total (pure ocean cells are excluded). We define an ozone "episode" as any occurrence, in a model grid cell, of a 4-h average surface ozone mixing ratio greater than $80 \mathrm{ppbv}$ (the U.S. EPAs 8 -h primary standard for surface ozone). Note that with the above definition there could be more than one ozone episode in a day. The 4-h averaging period corresponds to the frequency at which the gas-phase chemistry and aerosol modules are integrated. The United States Environmental Protection Agency's (US EPA) averaging period for the primary ozone standard is $8 \mathrm{~h}$. The choice of the averaging period, i.e., 4-h vs. 8-h, had a negligible effect on the number of ozone episodes.

\subsection{Overview of the predicted regional climate change}

As discussed in Racherla and Adams (2006), it takes approximately three months during the six-month model initialization period for the surface layer air temperatures to equilibrate to the changed ocean boundary conditions, resulting in an increase in the global annual-average values of the surface air temperature by $1.7^{\circ} \mathrm{C}$, the lower tropospheric specific humidity by $0.9 \mathrm{~g} \mathrm{H}_{2} \mathrm{O} / \mathrm{kg}$ air, and the precipitation by $0.15 \mathrm{~mm} \mathrm{day}^{-1}$. The corresponding changes in some key ozone related meteorological variables in the surface layer (984-934 hPa) of the eastern United States are provided in Table 1. The values shown correspond to 10-year domainaverages, May through September, which we consider to be fairly representative of the "ozone season" over the United States. The spatial distribution of the predicted temperature and absolute humidity changes (not shown) compare well with other GCM's predictions for the eastern United States provided in the IPCC TAR (IPCC, 2001). The spatial distri- bution of the cloud cover changes (not shown) corresponds, in general, to a reduction over coastal grid cells and increases over inland cells. Based on the cloud cover changes from separate 50-year climate-only simulations, we found, however, that the land-ocean cloud cover changes are not statistically significant at a $95 \%$ confidence level.

\subsection{Modeled ozone vs. observed: Eastern U.S.}

Figure 1a shows modeled (10-year average; PC simulation) and observed average maximum daily 8 -h average $\mathrm{O}_{3}$ concentrations (hereafter referred to as $\mathrm{MDA} 8-\mathrm{O}_{3}$ ) in the surface layer of the eastern United States during the summertime (June-Aug), while Fig. 1b shows differences between the modeled and observed summertime $M D A 8-O_{3}$. The observed values correspond to much higher resolution data from the U.S. EPA's Aerometric Information Retrieval System (available at http://www.epa.gov/ttn/airs/airsaqs/) for the years 1993 to 2000 , regridded onto the $4^{\circ}$ latitude by $5^{\circ}$ longitude grid of the model. It can be seen from Fig. $1 \mathrm{~b}$ that the model simulates within +5 ppbv the $\mathrm{MDA} 8-\mathrm{O}_{3}$ in the northeast and midatlantic states, a region in which the observed MDA8- $\mathrm{O}_{3}$ is generally the highest. The discrepancies between the modeled and observed MDA8- $\mathrm{O}_{3}$ are most significant in a few southern states (over predicts by 10-20 ppbv), wherein the natural isoprene emissions are high, and the midwestern states (under predicts by $10-20 \mathrm{ppbv}$ ). Although we have not investigated in further detail the mechanisms contributing to these discrepancies, they are likely related to the somewhat poor simulation (compared to regional-urban air quality models) of VOC-NO $\mathrm{N}_{\mathrm{x}}$ limitations, as is the case with most global models.

We also refer the interested reader to pertinent and detailed studies by Fiore et al. (2002) and Fiore et al. (2003), performed using the GEOS-Chem global model of tropospheric chemistry (Bey et al., 2001), with which the "unified" model shares a common heritage. The aforementioned 

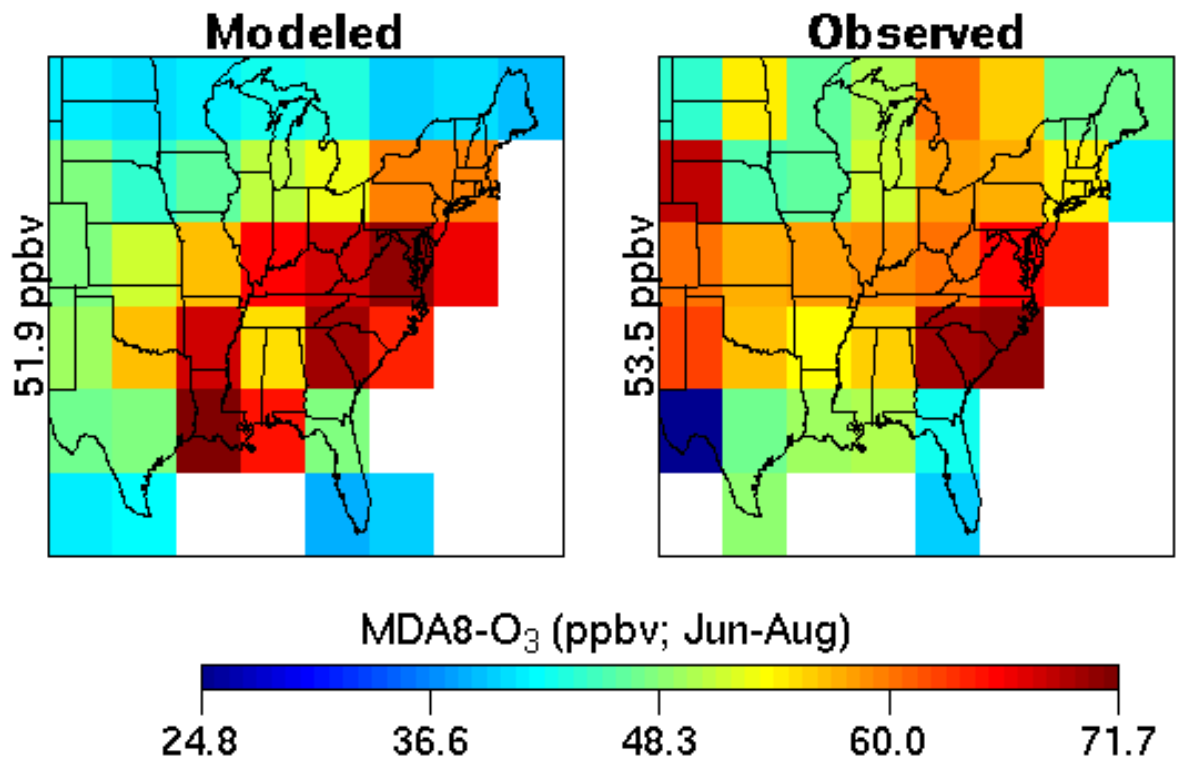

Fig. 1a. Modeled (left panel) and observed (right panel) average maximum daily 8-h average (MDA8) ozone concentrations (June-Aug) in the surface layer of the eastern United States. The modeled values (10-year average) correspond to a climate representative of the 1990s. The observed values correspond to much higher resolution data from the U.S. EPA's Aerometric Information Retrieval System for the years 1993 to 2000 , regridded onto the $4^{\circ}$ latitude by $5^{\circ}$ longitude grid of the model. In each case, the mean is displayed to the left of the panel. White cells are pure-ocean grid cells, or those that do not have observations in them.

studies show that the GEOS-Chem model at $4^{\circ} \times 5^{\circ}$ resolution describes quite well regional high- $\mathrm{O}_{3}$ events, although the local maxima is not captured. They conclude that the GEOS-Chem model captures the synoptic-scale processes responsible for the observed temporal variability of surface $\mathrm{O}_{3}$ concentrations, including high- $\mathrm{O}_{3}$ episodes. Of course, it must be noted that the spatiotemporal resolution of the model significantly impacts the signature of urban-regional ozone episodes, leading to different results on the number, frequency and duration of ozone events than observed.

\section{Results}

\subsection{Ozone episodes}

Figure 2 shows box-and-whisker plots of the predicted surface $\mathrm{O}_{3}$ mixing ratios in the surface layer of the eastern United States for the PC and FC simulations. These data are not spatially averaged. The model predicts practically zero change in the spatiotemporally averaged $\mathrm{O}_{3}$ mixing ratios, as can be seen from the nearly identical surface $\mathrm{O}_{3}$ median values for the PC and FC simulations. The most noticeable difference between the $\mathrm{PC}$ and $\mathrm{FC}$ simulation surface $\mathrm{O}_{3}$ distributions, however, is in the upper extreme, wherein the model predicts a $5 \mathrm{ppbv}$ increase in the 95 th percentile value for the FC simulation. Racherla and Adams (2006) also previously found a small increase (1 ppbv) in the annual mean surface $\mathrm{O}_{3}$ mixing ratio over the eastern United States but large in-

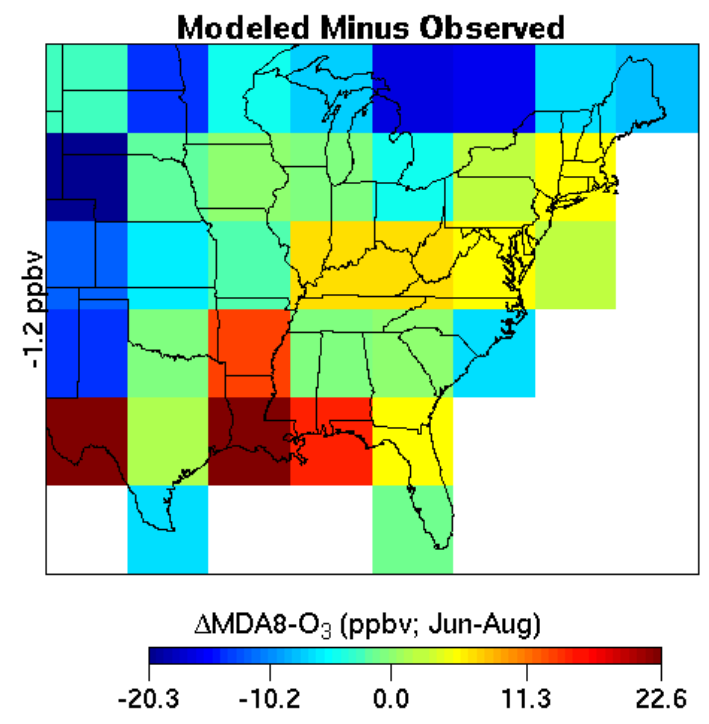

Fig. 1b. Differences between modeled and observed average maximum daily 8-h average (MDA8) ozone concentrations (June-Aug) in the surface layer of the eastern United States. The mean difference is displayed to the left of the panel. See Sect. 2.6 and the caption for Fig. 1a for details.

creases in the range of $3-9 \mathrm{ppbv}$ during the summertime in the FC simulation. 


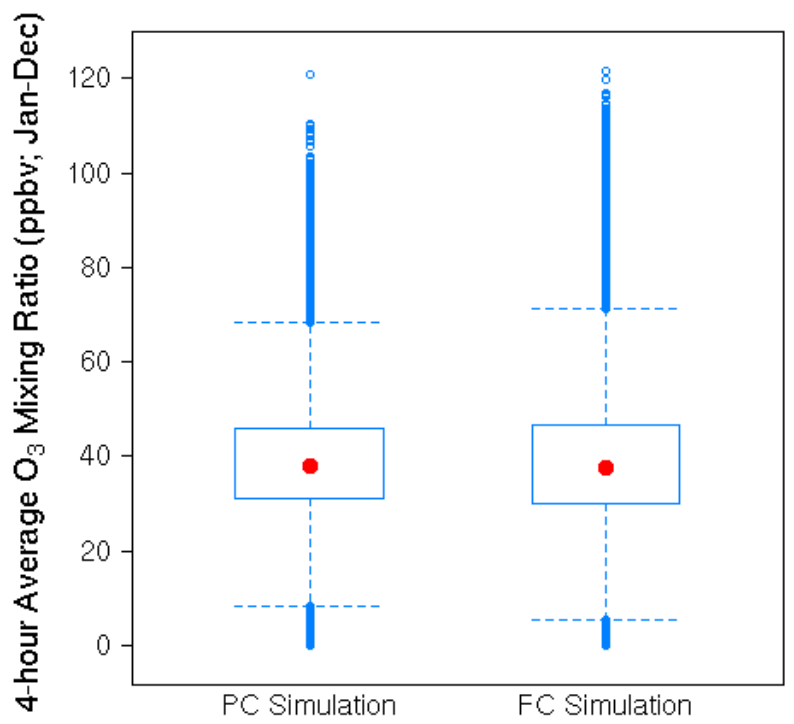

Fig. 2. Box and whisker plots of the 4-h average surface layer (984$934 \mathrm{hPa}$ ) ozone mixing ratios over the eastern United States (105$65^{\circ} \mathrm{W}$ and $24-48^{\circ} \mathrm{N}$ ) for the present climate (PC) and future climate (FC) simulations. These data are not spatially averaged; they correspond to 4-h average surface ozone mixing ratios, 10 simulation years worth, saved over the eastern United States, corresponding to 38 model cells in total (pure ocean cells are excluded). The central box shows the data between the upper and lower quartiles (25th and 75th percentile), with the median represented by a dot; whiskers go out to the 5th and 95th percentiles of the data. Values beyond the 5th and 95th percentile are shown as individual data points.

The difference between the PC and FC simulations surface $\mathrm{O}_{3}$ distributions is emphasized in Fig. 3, which shows truncated surface $\mathrm{O}_{3}$ probability distribution functions (PDFs) for the two simulations. The model predicts an increased probability of high- $\mathrm{O}_{3}$ events in the FC simulation, with the largest increase occurring in the $80-90 \mathrm{ppbv}$ range. Recall that we defined an $\mathrm{O}_{3}$ episode as any occurrence, in a model grid cell, of a 4-h average surface $\mathrm{O}_{3}$ mixing ratio greater than 80 ppbv (Sect. 2.4). These results show that the severity and frequency of $\mathrm{O}_{3}$ episodes increases in the $\mathrm{FC}$ simulation.

Figure 4a shows the model predicted spatial distribution of the yearly frequencies (10-year average) of $\mathrm{O}_{3}$ episodes over the eastern United States in the PC simulation, while Fig. $4 \mathrm{~b}$ shows the spatial distribution of the differences (FC simulation minus PC simulation) in the yearly frequencies of $\mathrm{O}_{3}$ episodes. The model predicts an increased frequency of $\mathrm{O}_{3}$ episodes over most of the eastern United States, with substantial increases of 20-40 episodes per year over some southeast and midatlantic states. We examined the statistical significance of the predicted changes by performing a Student's $t$ test upon the 10-year distributions of the yearly frequency of $\mathrm{O}_{3}$ episodes in individual grid cells for the PC

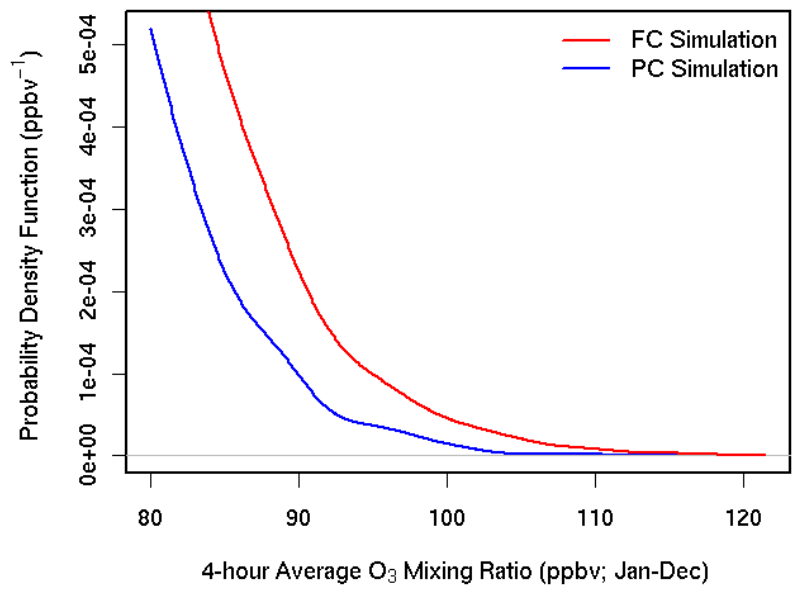

Fig. 3. Probability density function of the 4-h average surface layer (984-934 hPa) ozone mixing ratios over the eastern United States $\left(105-65^{\circ} \mathrm{W}\right.$ and $\left.24-48^{\circ} \mathrm{N}\right)$ for the present climate $(\mathrm{PC})$ and future climate (FC) simulations; only the upper tail (ozone mixing ratio $\geq 80 \mathrm{ppbv}$ ) of the distribution is shown here. These data are not spatially averaged; they correspond to 4-h average surface ozone mixing ratios, 10 simulation years worth, saved over the eastern United States, corresponding to 38 model cells in total (pure ocean cells are excluded).

and FC simulations. The results of the $t$ test are also shown in Fig. 4b, wherein grid cells marked with an "X" are statistically significant at $95 \%$ confidence level i.e., $p<0.05$. It can be seen that the increases over the southeast and midatlantic United States are statistically significant. Collectively, these results show that the severity and frequency of $\mathrm{O}_{3}$ episodes over the eastern United States increases due to climate change, with substantial and statistically significant increases occurring over some southeast and midatlantic states.

Figure 5 shows the probability of an $\mathrm{O}_{3}$ episode occurring over the eastern United States during any 4-h period for the PC and FC simulations, January through December. We utilize the changes in $\mathrm{O}_{3}$ episode probability as a surrogate for the changes in length of the ozone season. As expected, for both PC and FC simulations, the summer months (June through August) display the highest probability for the occurrence of $\mathrm{O}_{3}$ episodes. While the largest absolute increases occur predominantly in the summer months, it is interesting to note the larger relative increases in episode probability in the FC simulation during the fall (September/October) and spring (April/May) seasons, which, generally, have very few $\mathrm{O}_{3}$ episodes under present-day meteorology and emissions. These findings suggest a lengthening of the ozone season over the eastern United States to include late spring and early fall months. In the subsequent sections we investigate in detail the factors contributing to these changes. 

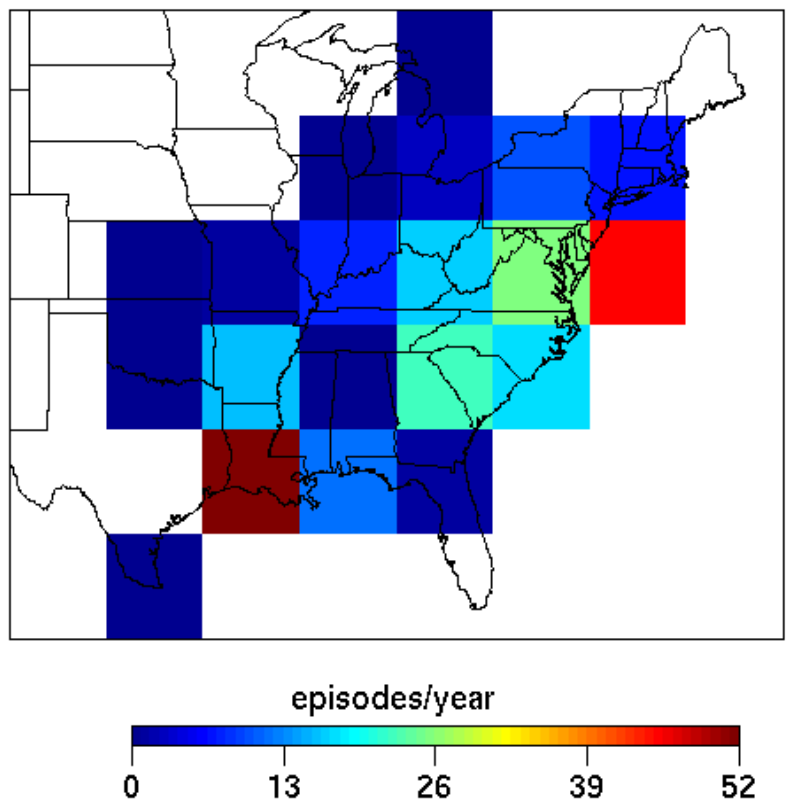

Fig. 4a. Average yearly frequency of ozone episodes (defined here as any occurrence in a grid cell of a 4-h average ozone mixing ratio greater than $80 \mathrm{ppbv})$ in the surface layer $(984-934 \mathrm{hPa})$ of the eastern United States corresponding to the present climate simulation. White cells are pure-ocean grid cells and/or those that do not have any episodes.

\subsection{Synoptic-scale circulation changes?}

Some previous modeling studies (Mickley et al., 2004; Murazaki and Hess, 2006) have suggested that the severity and frequency of future summertime air pollution episodes in the northeastern and midwestern United States will increase due to reduced extratropical cyclone frequency in a warmer climate. To investigate changes in synoptic-scale circulations over the eastern United States in the FC simulation, we examined the anomalies in the daily average sea level pressure (SLP), May through September, over the midwest (105$\left.90^{\circ} \mathrm{W} ; 36-52^{\circ} \mathrm{N}\right)$ and northeast $\left(90-65^{\circ} \mathrm{W} ; 36-52^{\circ} \mathrm{N}\right)$. Figure 6 shows a comparison between the cumulative distribution function of the daily average SLP anomaly over the midwestern United States in the PC and FC simulations, respectively. It can be seen that the distributions follow one another closely; the result for the northeast (not shown) is similar. The above result suggests that the simulated synoptic-scale circulations in those regions are not significantly different between the PC and FC simulations. When the same analysis is performed in individual grid cells, there is up to a $4 \%$ difference in the cumulative probabilities at the low-end (decrease) and the high-end (increase). Using a Kolmogorov-Smirnov test, we found that these changes are far from significant, however, as the p-values are much greater than 0.05 .

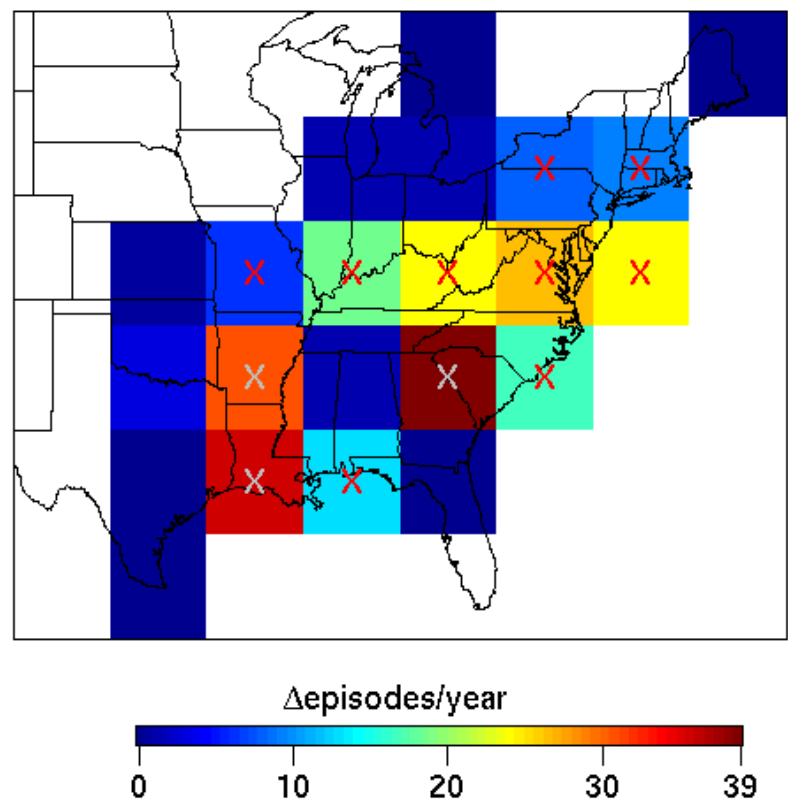

Fig. 4b. Differences (future climate simulation minus present climate simulation) in the average yearly frequency of ozone episodes in the surface layer (984-934 hPa) of the eastern United States. Grid cells marked with an "X" have a statistically significant $(p<0.05)$ difference in the yearly frequency of ozone episodes, which is determined using a Student's t test upon the 10-year distributions of the yearly frequency of ozone episodes in each model grid cell for the present and future climate simulations. White cells are pure-ocean grid cells and/or those that do not have any episodes in both present and future climate simulations.

The contribution of these simulated changes in the synoptic-scale circulations to the predicted changes in $\mathrm{O}_{3}$ episodes is not clear. Regardless, our analysis (Sect. 3.3 onwards) shows that the changes in $\mathrm{O}_{3}$ chemical production contribute the most towards the increases in $\mathrm{O}_{3}$ episodes in the FC simulation. In contrast to the cited earlier work, we do not find unambiguous evidence of synoptic-scale circulation changes driving the increase in $\mathrm{O}_{3}$ episodes. Some possible reasons for this apparent discrepancy with previous studies are: a) the different SSTs that we utilize; and, b) the different methodology that we have employed to detect circulation changes, i.e., SLP anomaly distributions as opposed to a cyclone tracking method (Mickley et al., 2004).

\subsection{Average ozone}

Figure 7 shows the spatial distribution of the differences (FC simulation minus PC simulation) in the average (May-Sep) $\mathrm{O}_{3}$ concentrations in the surface layer of the eastern United States. It can be seen that the model predicts increases in the average $\mathrm{O}_{3}$ concentrations along the relatively more polluted coastal grid cells, and decreases further west. The factors contributing to these changes are better understood with 
Table 2. Seasonal surface layer (984-934 hPa) ozone budget over the Southeast and Midatlantic United States $\left(95-75^{\circ} \mathrm{W}\right.$ and $\left.28-40^{\circ} \mathrm{N}\right)$ for the present climate (PC) and future climate (FC) simulations. The budget presented here is for the odd oxygen $\left(\mathrm{O}_{\mathrm{x}}\right)$ family defined as the sum of $\mathrm{O}_{3}, \mathrm{O}, \mathrm{NO}_{2}, 2 \times \mathrm{NO}_{3}, 3 \times \mathrm{N}_{2} \mathrm{O}_{5}, \mathrm{HNO}_{4}, \mathrm{HNO}_{3}$, and the peroxyacylnitrates.

\begin{tabular}{lrrrrrrrr}
\hline & \multicolumn{2}{c}{ DJF } & \multicolumn{2}{c}{ MAM } & \multicolumn{2}{c}{ JJA } & \multicolumn{3}{c}{ SON } \\
\cline { 2 - 9 } & PC & FC & PC & FC & PC & FC & PC & FC \\
\hline Sources (Tg O 3 / 3 months) & & & & & & & & \\
$\quad$ Chemical production & 2.3 & 2.6 & 7.8 & 8.6 & 12.5 & 13.6 & 6.2 & 7.2 \\
Sinks (Tg O3/3 months) & & & & & & & & \\
$\quad$ Dry deposition & 1.5 & 1.6 & 4.6 & 4.6 & 5.5 & 5.6 & 3.2 & 3.5 \\
$\quad$ Chemical loss & 0.8 & 0.9 & 2.1 & 2.3 & 3.7 & 4.2 & 1.9 & 2.2 \\
$\quad$ Net transport & 0.0 & 0.1 & 1.1 & 1.7 & 3.3 & 3.8 & 1.1 & 1.5 \\
Burden (Gg) & 65.6 & 65.3 & 101.9 & 99.7 & 106.5 & 109.3 & 85.9 & 89.1 \\
Lifetime (Hours) & 61.7 & 55.2 & 28.9 & 25.7 & 18.8 & 17.8 & 30.4 & 27.0 \\
\hline
\end{tabular}

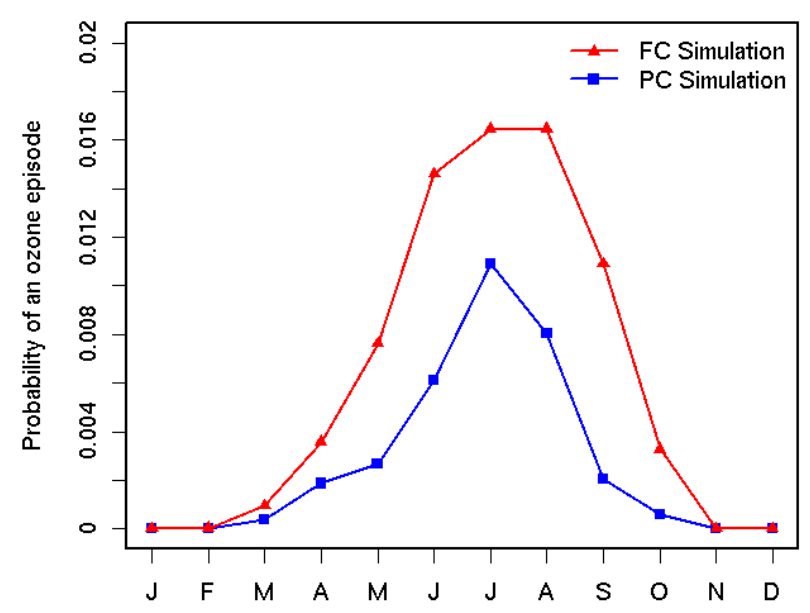

Fig. 5. The probability of an ozone episode (per model time step and grid cell) occuring over the eastern United States $\left(105-65^{\circ} \mathrm{W}\right.$ and $24-48^{\circ} \mathrm{N}$ ) for the present climate (PC) and future climate (FC) simulations. Months $\mathrm{J}$ through D refer to months January through December. Monthly probabilities are calculated by normalizing the domain-wide monthly 4-h average ozone exceedances of $80 \mathrm{ppbv}$ by the product of the number of grid cells (eastern United States) and simulation time steps for each month.

a surface layer $\mathrm{O}_{3}$ budget (see Table 2). We focus on the midatlantic and southeastern states, wherein the model predicts significant increases in the average $\mathrm{O}_{3}$ as well as high$\mathrm{O}_{3}$ events. The budget shown in Table 2 is actually for odd oxygen $\left(\mathrm{O}_{\mathrm{x}}\right)$, which is defined here as the sum of $\mathrm{O}_{3}, \mathrm{O}$, $\mathrm{NO}_{2}, 2 \times \mathrm{NO}_{3}, 3 \times \mathrm{N}_{2} \mathrm{O}_{5}, \mathrm{HNO}_{4}, \mathrm{HNO}_{3}$, and the peroxyacylnitrates. It can be seen from Table 2 that two consistent features of the seasonal surface $\mathrm{O}_{3}$ response to climate change are the increased $\mathrm{O}_{3}$ chemical production (hereafter abbreviated as $\mathrm{OCP}$ ) and shorter average $\mathrm{O}_{3}$ lifetime. The spatial and seasonally averaged $\mathrm{O}_{3}$ burden in the midatlantic and southeastern states increases because, on an average, the ef-

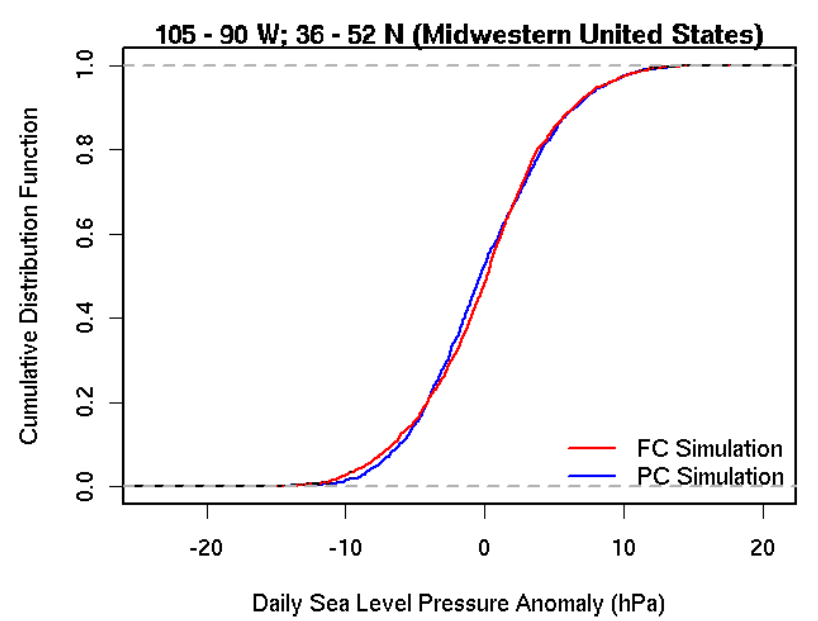

Fig. 6. Cumulative distribution function (CDF) of the daily average sea level pressure anomaly (daily spatial average minus mean) over the midwestern United States $\left(105-90^{\circ} \mathrm{W} ; 36-52^{\circ} \mathrm{N}\right)$ for the present climate simulation (blue color line) and the future climate simulation (red color line). The Y-axis represents the CDF and the $\mathrm{X}$-axis the daily average SLP anomaly (units of $\mathrm{hPa}$ ).

fect of increased OCP prevails over the effect of increased $\mathrm{O}_{3}$ removal rate. Further west (budget not shown) the effect of increased $\mathrm{O}_{3}$ removal rate prevails, however, leading to decreases in the average $\mathrm{O}_{3}$ concentrations.

Table 3 provides a summary of some key factors contributing to increased OCP in the southeast and midatlantic United States. Increased natural isoprene emissions result in increases in the concentrations of organic peroxy radicals $\left(\mathrm{RO}_{2}\right)$ and to some extent the hydroperoxy radical $\left(\mathrm{HO}_{2}\right)$. Most of the increase in $\mathrm{HO}_{2}$ concentrations comes from the increased absolute humidity alone, however. The net effect of these increased peroxy radical concentrations in high$\mathrm{NO}_{\mathrm{x}}$ regions is an increased OCP through $\mathrm{NO}+\mathrm{RO}_{2}$ and $\mathrm{NO}+\mathrm{HO}_{2}$. It is not clear as to what extent the decreased 
Table 3. Seasonal variations of a number of factors controlling ozone chemical production in the surface layer (984-934 hPa) of the Southeast and Midatlantic United States $\left(95-75^{\circ} \mathrm{W}\right.$ and $\left.28-40^{\circ} \mathrm{N}\right)$ for the present climate (PC) and future climate (FC) simulations. In this table, $\mathrm{RO}_{2}$ includes peroxy radicals (lumped) formed from the oxidation of all non-methane VOCs with $\mathrm{OH}$.

\begin{tabular}{|c|c|c|c|c|c|c|c|c|}
\hline & \multicolumn{2}{|c|}{ DJF } & \multicolumn{2}{|c|}{ MAM } & \multicolumn{2}{|c|}{ JJA } & \multicolumn{2}{|c|}{ SON } \\
\hline & $\mathrm{PC}$ & $\mathrm{FC}$ & $\mathrm{PC}$ & $\mathrm{FC}$ & $\mathrm{PC}$ & $\mathrm{FC}$ & $\mathrm{PC}$ & FC \\
\hline $\mathrm{HO}_{2}\left(10^{8}\right.$ molecules $\left.\mathrm{cm}^{-3}\right)$ & 0.23 & 0.28 & 0.89 & 1.03 & 1.69 & 1.87 & 0.70 & 0.92 \\
\hline $\mathrm{RO}_{2}\left(10^{4}\right.$ molecules $\left.\mathrm{cm}^{-3}\right)$ & 0.15 & 0.20 & 0.57 & 0.73 & 1.52 & 1.87 & 0.65 & 0.94 \\
\hline Isoprene emissions ( $\mathrm{Tg} / 3$ months) & 0.25 & 0.30 & 1.53 & 1.81 & 3.89 & 4.55 & 1.33 & 1.77 \\
\hline $\mathrm{NO}+\mathrm{HO}_{2}\left(\mathrm{Tg} \mathrm{O} \mathrm{O}_{3} / 3\right.$ months $)$ & 1.32 & 1.45 & 4.16 & 4.50 & 5.96 & 6.28 & 3.20 & 3.63 \\
\hline $\mathrm{NO}+\mathrm{RO}_{2}\left(\mathrm{Tg} \mathrm{O}_{3} / 3\right.$ months $)$ & 0.72 & 0.83 & 2.81 & 3.19 & 5.29 & 5.96 & 2.34 & 2.87 \\
\hline $\mathrm{NO}+\mathrm{CH}_{3} \mathrm{O}_{2}\left(\mathrm{Tg} \mathrm{O}_{3} / 3\right.$ months $)$ & 0.25 & 0.28 & 0.81 & 0.88 & 1.24 & 1.32 & 0.62 & 0.71 \\
\hline
\end{tabular}

cloud cover (see Table 1) alone, in the form of increased photolysis rates, contributed to the increased OCP.

The surface $\mathrm{O}_{3}$ budget (Table 2) shows that the shorter $\mathrm{O}_{3}$ lifetime during all seasons in the $\mathrm{FC}$ simulation occurs through a combination of changes in the dry deposition removal rates, total chemical loss rates, and net transport. Note that because the burdens are different in the PC and FC simulations in each season, it is important that the contribution of each loss mechanism to the overall lifetime change is considered rather than the absolute change in the loss itself. It can be seen that, with the exception of the summer months (June/July/Aug), increased dry deposition loss rates contribute most to the shorter $\mathrm{O}_{3}$ lifetime. During the summer months, however, increased chemical loss rates and net transport contribute to the overall shorter $\mathrm{O}_{3}$ lifetime, while dry deposition loss rates remain nearly unchanged.

The increased chemical loss rates are due to the increases in $\mathrm{O}\left({ }^{1} \mathrm{D}\right)+\mathrm{H}_{2} \mathrm{O}, \mathrm{O}_{3}+\mathrm{HO}_{2}$, and $\mathrm{O}_{3}+$ isoprene, as a result of the increases in absolute humidity and natural isoprene emissions. The increased dry deposition removal rate during the fall, spring, and winter months is due to reduced aerodynamic and quasi-laminar sublayer resistance $\left(R_{A}\right)$. Because key surface parameters such as the leaf area index are being held constant between the PC and FC simulations, the change in the surface resistance itself has a negligible effect. One factor that explains the reduced $R_{A}$ during the aforementioned seasons is the increased surface wind speeds (shown for May-Sep in Table 1), which also explains the increased net transport. We did not attempt to diagnose in further detail the changes in $R_{A}$, however.

3.4 The contribution of increased natural isoprene emissions

In order to estimate the contribution of increased natural isoprene emissions to the model predicted changes in surface $\mathrm{O}_{3}$ over the eastern United States, we performed additional sensitivity simulations ( 5 consecutive summers), with the A2 2050s climate, wherein the model evaluated isoprene emissions were scaled down uniformly by a factor of 1.2 , glob-

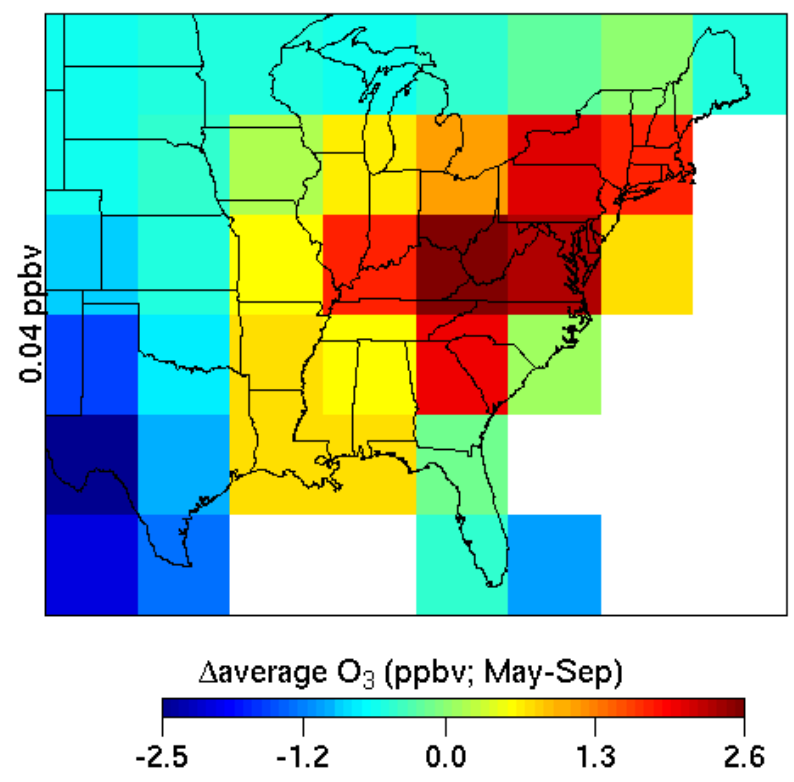

Fig. 7. Differences (future climate simulation minus present climate simulation) in the average (May-Sep) ozone mixing ratio (ppbv) in the surface layer $(984-934 \mathrm{hPa})$ of the eastern United States. The mean difference is displayed to the left of the panel. White cells are pure-ocean grid cells.

ally. Hereafter, we refer to these simulations collectively as the FC-PISOP simulation. The factor of 1.2 corresponds to the 10-year average of the ratio of isoprene emissions in the FC to the PC simulations over the eastern United States. Note that this is a purely hypothetical modeling experiment, as it is not possible to completely separate the effects of natural isoprene emissions and climate change.

The results from the FC-PISOP simulation for summertime $\mathrm{O}_{3}$ episodes is shown in Fig. 8. This figure (and Figs. 912) has three panels displaying the $\mathrm{O}_{3}$ effects of the following: a) climate change and increased isoprene emissions (i.e., FC simulation minus PC simulation); b) climate change alone (i.e, FC-PISOP simulation minus PC simulation); and, 

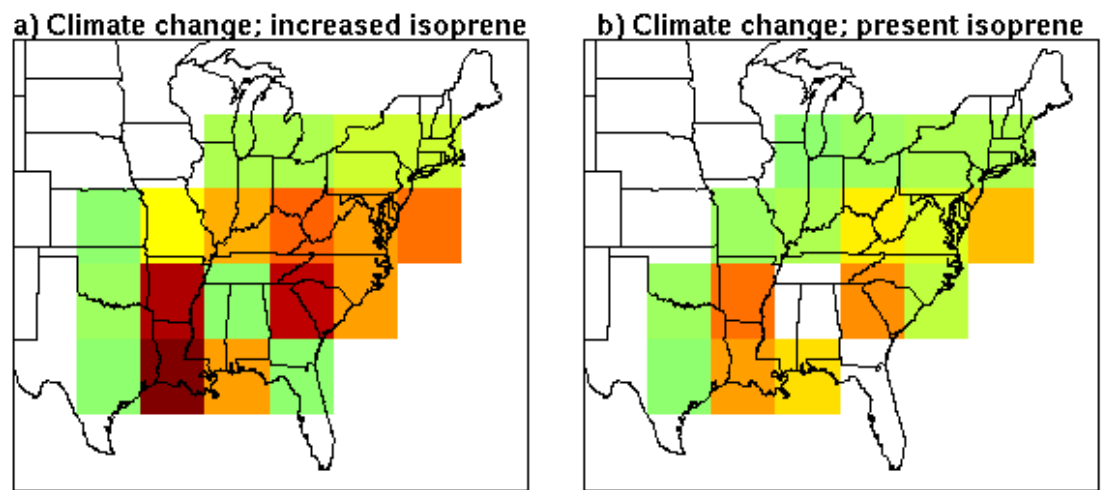

$\Delta$ episodes (Jun-Aug)

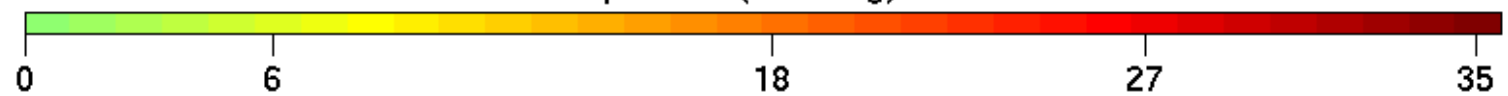

Fig. 8. Differences in the summertime (June/July/Aug) frequency (5-year average) of ozone episodes (defined here as any occurrence in a grid cell of a 4-h average ozone mixing ratio greater than $80 \mathrm{ppbv}$ ) in the surface layer (984-934 hPa) of the eastern United States corresponding to: (a) climate change and increased isoprene emissions (i.e., FC simulation minus PC simulation); (b) climate change with present isoprene emissions (i.e., FC-PISOP simulation minus PC simulation); and, (c) future climate with increased isoprene emissions (i.e., FC simulation minus FC-PISOP simulation). White cells are pure-ocean grid cells and/or those that do not have any episodes in the simulations under comparison.
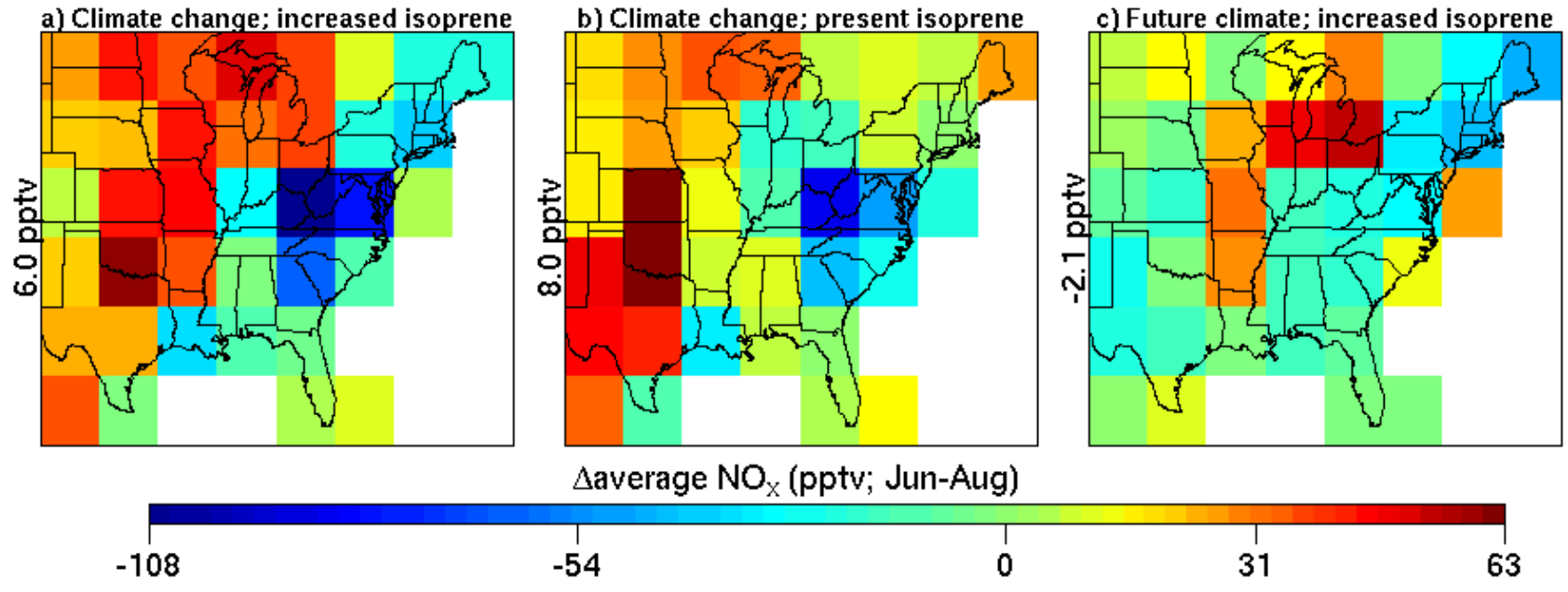

Fig. 9. Differences in the summertime (June/July/Aug) $\mathrm{NO}_{\mathrm{x}}$ mixing ratios (pptv) in the surface layer (984-934 hPa) of the eastern United States corresponding to: (a) climate change and increased isoprene emissions (i.e., FC simulation minus PC simulation); (b) climate change with present isoprene emissions (i.e., FC-PISOP simulation minus PC simulation); and, (c) future climate with increased isoprene emissions (i.e., FC simulation minus FC-PISOP simulation). In each case, the mean difference is displayed to the left of the panel. White cells are pure-ocean grid cells.

c) increased isoprene emissions alone (i.e., FC simulation minus FC-PISOP simulation). It is evident from Fig. 8 that in the FC simulation $50-60 \%$ of the increase in summertime $\mathrm{O}_{3}$ episodes over the southeast and midatlantic United States is due to increased isoprene emissions alone. We examine next the mechanisms that contribute to the remainder of the increase.

\subsection{PAN-NO ${ }_{x}$ chemistry}

Sillman and Samson (1995); Aw and Kleeman (2003); Dawson et al. (2007) show that summertime $\mathrm{O}_{3}$ concentrations increase as temperature increases, with the $\mathrm{O}_{3}$ sensitivity largely driven by a decrease in the net formation of PAN, which results in increases in $\mathrm{NO}_{\mathrm{x}}$. Changes in the 

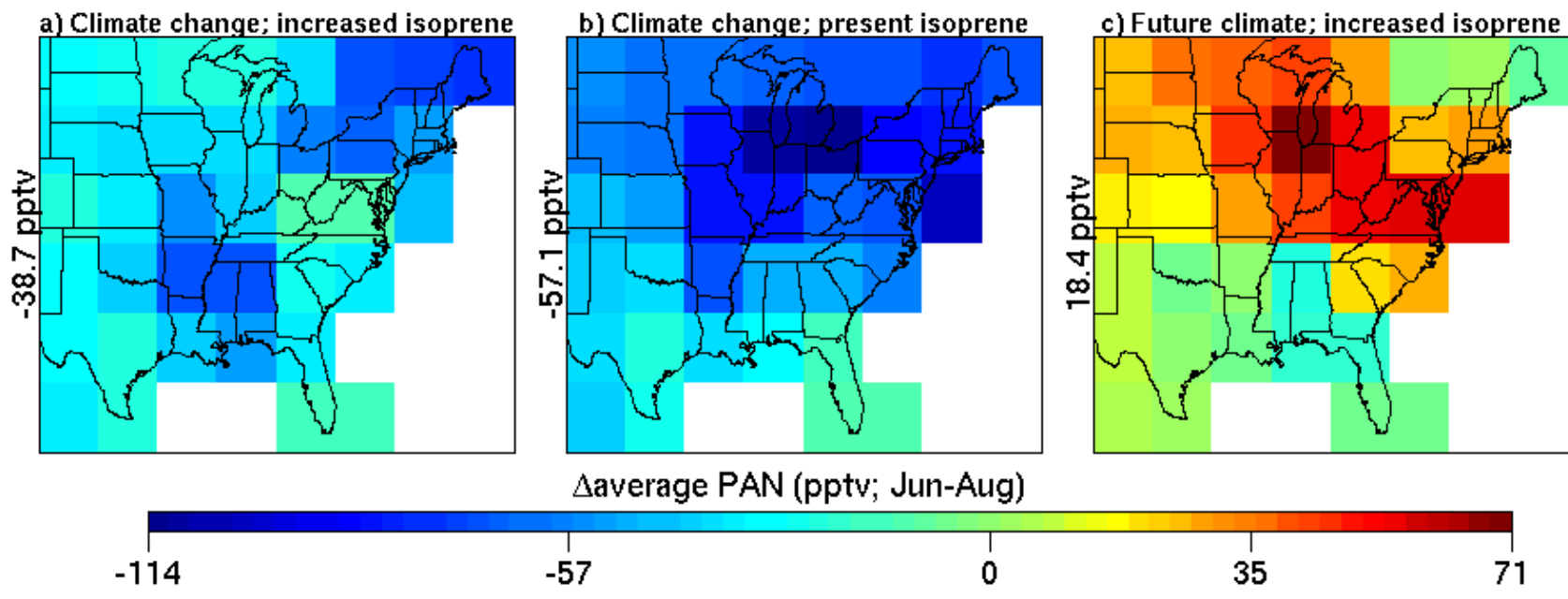

Fig. 10. As in Fig. 8 but for peroxy acetyl nitrate (PAN) mixing ratios (pptv).
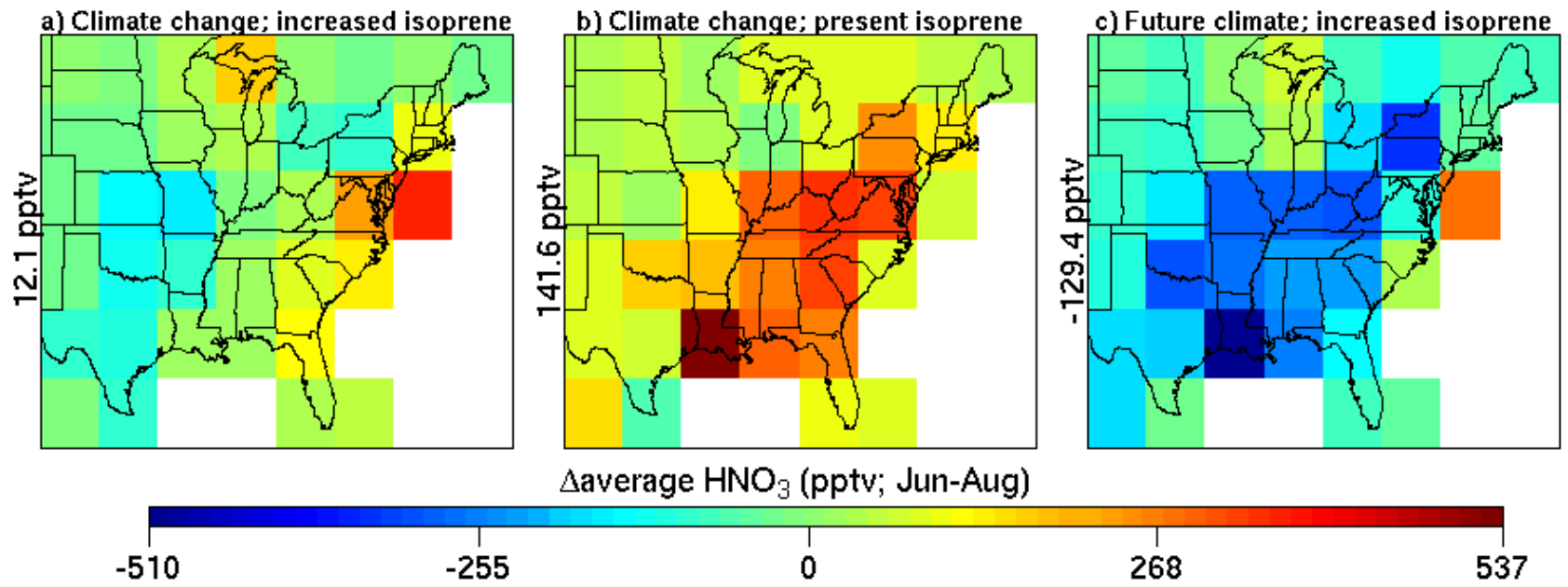

$\Delta$ average $\mathrm{HNO}_{3}$ (pptv; Jun-Aug)

Fig. 11. As in Fig. 8 but for nitric acid $\left(\mathrm{HNO}_{3}\right)$ mixing ratios (pptv).

summertime $\mathrm{NO}_{\mathrm{x}}$ concentrations are shown in Fig. 9, while those for PAN are shown in Fig. 10. The most noticeable feature (see panels a/b of Figs. 9 and 10) is that although the PAN concentrations decrease throughout the eastern United States in the FC/FC-PISOP simulations, the $\mathrm{NO}_{\mathrm{x}}$ concentrations increase only in relatively low $-\mathrm{O}_{3}$ regions such as the midwestern United States. This result can be explained as follows. In the high- $\mathrm{O}_{3}$ regions, increased OCP by $\mathrm{NO}+\mathrm{HO}_{2} / \mathrm{RO}_{2}$ in the $\mathrm{FC} / \mathrm{FC}$-PISOP simulations results in a higher $\mathrm{NO}_{2}: \mathrm{NO}$ ratio. As a result, more $\mathrm{NO}_{\mathrm{x}}$ is present as $\mathrm{NO}_{2}$, where it is more likely to undergo oxidation to $\mathrm{HNO}_{3}$, and be eventually removed from the atmosphere. Evidence for this explaination, i.e., increased $\mathrm{HNO}_{3}$ concentrations in the high- $\mathrm{O}_{3}$ regions in the $\mathrm{FC} / \mathrm{FC}-\mathrm{PISOP}$ simulations, is presented in Fig. 11 (see panels a/b).
The PAN increase between the FC-PISOP and the FC simulations (Fig. 10c) further isolates the effect of increased isoprene emissions on the $\mathrm{NO}_{2}$ : $\mathrm{NO}$ ratio. That PAN increase, in fact, points to an increase in the $\mathrm{NO}_{2}: \mathrm{NO}$ ratio, because the steady state concentration of PAN is proportional to the $\mathrm{NO}_{2}$ : $\mathrm{NO}$ ratio (Seinfeld and Pandis, 1998). In this case the $\mathrm{HNO}_{3}$ concentrations decrease (see Fig. 11c), however, as the average hydroxyl radical concentrations decrease (not shown) due to increased isoprene oxidation. These findings serve to illustrate the complex web of interactions that constitute the response of surface $\mathrm{O}_{3}$ to climate change. In summary, we find that the decreased PAN in the FC simulation, as a result of warmer temperatures, frees up additional $\mathrm{NO}_{\mathrm{x}}$, resulting in increased OCP. At the same time, because of increased $\mathrm{HNO}_{3}$ formation (by $\mathrm{NO}_{2}+\mathrm{OH}$ ) in high- 

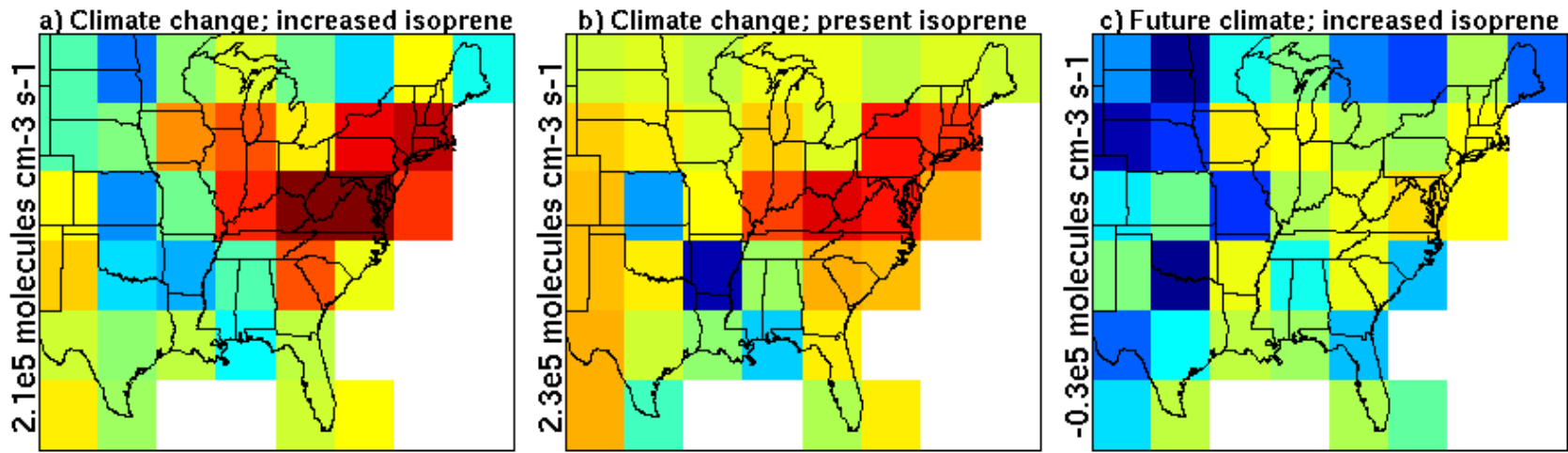

$\Delta \mathrm{NO}+\mathrm{HO}_{2}$ (1e5 molecules cm-3 s-1; average, Jun-Aug)

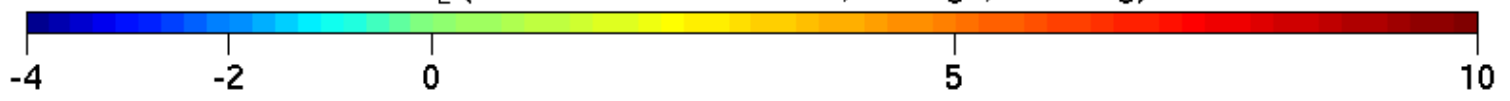

Fig. 12. Differences in the summertime (June/July/Aug) ozone chemical production $\left(10^{5}\right.$ molecules $\left.\mathrm{cm}^{-3} \mathrm{~s}^{-1}\right)$ by $\mathrm{NO}+\mathrm{HO}_{2}(5-\mathrm{year}$ average) in the surface layer (984-934 hPa) of the eastern United States corresponding to: (a) climate change and increased isoprene emissions (i.e., FC simulation minus PC simulation); (b) climate change with present isoprene emissions (i.e., FC-PISOP simulation minus PC simulation); and, (c) future climate with increased isoprene emissions (i.e., FC simulation minus FC-PISOP simulation). In each case, the mean difference is displayed to the left of the panel. White cells are pure-ocean grid cells.

$\mathrm{O}_{3}$ regions, however, the "average" $\mathrm{NO}_{\mathrm{x}}$ concentrations actually decrease.

\section{$3.6 \quad \mathrm{HO}_{\mathrm{x}}$ chemistry}

The FC-PISOP simulation showed that nearly half the increase in $\mathrm{O}_{3}$ episodes in the $\mathrm{FC}$ simulation is attributable to the increased natural isoprene emissions. Given the lack of unambiguous evidence linking the increase in $\mathrm{O}_{3}$ episodes in the FC simulation to synoptic-scale circulation changes, the remainder of the increase in $\mathrm{O}_{3}$ episodes is also likely related to OCP, particularly the changes in $\mathrm{HO}_{\mathrm{x}}$. This is evident from Table 3, which shows that upto $50 \%$ of the increased OCP in each season is due to increases in $\mathrm{NO}+\mathrm{HO}_{2}$.

We examined the fraction of the increased OCP by $\mathrm{NO}+\mathrm{HO}_{2}$ that is due to climate change alone. This is shown in Fig. 12. Panels $\mathrm{a} / \mathrm{b}$ of this figure clearly show that the increased $\mathrm{OCP}$ by $\mathrm{NO}+\mathrm{HO}_{2}$ in the $\mathrm{FC}$ simulation is largely due to climate change alone. Also, a comparison of Fig. 12 with Figs. 7/8 shows that, with the exception of a few grid cells, the increases in OCP by $\mathrm{NO}+\mathrm{HO}_{2}$ coincide with the increases in average $\mathrm{O}_{3}$ and $\mathrm{O}_{3}$ episodes. This increased OCP by $\mathrm{NO}+\mathrm{HO}_{2}$ is due to the increased $\mathrm{HO}_{2}$ concentrations associated with increased absolute humidity, and the increased $\mathrm{NO}_{\mathrm{x}}$ concentrations associated with decreased PAN (see Sect. 3.4). We conclude from these results that a significant fraction of the predicted increase in $\mathrm{O}_{3}$ episodes and average $\mathrm{O}_{3}$ in the FC simulation, not associated with the increased natural isoprene emissions, is due to the increases in $\mathrm{OCP}$ by $\mathrm{NO}+\mathrm{HO}_{2}$.
The changes in $\mathrm{OCP}$ by $\mathrm{NO}+\mathrm{HO}_{2}$ merit further attention. In the absence of increases in isoprene emissions, climate change increases the OCP by $\mathrm{NO}+\mathrm{HO}_{2}$ over most of the eastern United States (Fig. 12b). When isoprene emissions increase, however, the OCP by $\mathrm{NO}+\mathrm{HO}_{2}$ generally increases in high- $\mathrm{O}_{3}$ regions and decreases in low $-\mathrm{O}_{3}$ regions. One explanation for this behavior is that in the high- $\mathrm{O}_{3}$ regions, increased isoprene emissions promote $\mathrm{OCP}$ by $\mathrm{NO}+\mathrm{RO}_{2}$ and $\mathrm{NO}+\mathrm{HO}_{2}$ whereas, in the low $-\mathrm{O}_{3}$ regions, increased isoprene emissions promotes increased radical-radical cycling (e.g. $\mathrm{RO}_{2}-\mathrm{RO}_{2}, \mathrm{HO}_{2}-\mathrm{HO}_{2}$, etc.).

\subsection{The effect of interannual variability}

Our modeling shows that with only a few years (e.g. 2 years) of simulation data, it is difficult to separate the effects of interannual variability and future climate change on $\mathrm{O}_{3}$ episodes. This is illustrated in Table 4, wherein we show the 10-year average difference (FC simulation minus PC simulation) in the annual frequency of ozone episodes, and the ratio $(\rho)$ of the average difference to the standard error as a function of the number of simulation years for five select locations over the southeast and midatlantic United States. For the ratio's, the average difference is recalculated for the period under consideration, i.e., 1-year/5-year/10-year.

Utilizing the ratio $\rho$ defined above, we can estimate the fraction $(\eta)$ of the predicted change in annual $\mathrm{O}_{3}$ episodes that could be attributed to interannual variability alone, as shown below:

$\eta=\frac{1}{1+\rho}$ 
Table 4. The 10-year average difference (future climate simulation minus present climate simulation) in the annual frequency of ozone episodes, and the ratio of the average difference to the standard error as a function of the number of simulation years for five select locations over the Southeast and Midatlantic United States; for the ratio's, the average difference is recalculated for the period under consideration, i.e., 1-year/5-year/10-year.

\begin{tabular}{lcccc}
\hline & Average difference & \multicolumn{3}{c}{ Average difference : Standard error } \\
\cline { 3 - 5 } & & 1 years & 5 years & 10 years \\
\hline $95-90^{\circ} \mathrm{W}$ and $28-32^{\circ} \mathrm{N}$ & 50 & 1.7 & 4.6 & 4.6 \\
$95-90^{\circ} \mathrm{W}$ and $32-36^{\circ} \mathrm{N}$ & 36 & 1.2 & 3.9 & 3.4 \\
$85-80^{\circ} \mathrm{W}$ and 32-36 $\mathrm{N}$ & 46 & 2.1 & 5.9 & 5.8 \\
$85-80^{\circ} \mathrm{W}$ and 36-40 $\mathrm{N}$ & 25 & 2.0 & 4.6 & 4.3 \\
$80-75^{\circ} \mathrm{W}$ and 36-40 & 25 & 2.4 & 4.9 & 5.8 \\
\hline
\end{tabular}

Using Eq. (1) in Table 4 it can be seen that after 1 year $\eta$ varies from 0.30 to 0.46 , i.e., $30-46 \%$ of the difference in the annual frequency of $\mathrm{O}_{3}$ episodes could be attributed to interannual variability alone. The fraction drops to $14-20 \%$ for 5 years. It remains fairly constant thereafter. This means that with 5 years or more of simulation data, $80-85 \%$ of the predicted change in the annual frequency of $\mathrm{O}_{3}$ episodes could be attributed to climate change alone. We conclude from these results that it is necessary to utilize 5 years or more of simulation data in order to separate the effects of future climate change and interannual variability on $\mathrm{O}_{3}$ episodes.

\subsection{Discussion}

These results are associated with notable uncertainty. Firstly, the spatiotemporal resolution of the model makes it difficult to resolve accurately the boundary layer depth, VOC- $\mathrm{NO}_{\mathrm{x}}$ limitation, and coastal-land transitions, etc. Pertinent to these modeling results is the over-prediction of surface $\mathrm{O}_{3}$ concentrations in some southern states (see Fig. 1b and Sect. 2.6), wherein the model also predicts significant increases in $\mathrm{O}_{3}$ episodes due to climate change. Similar experiments utilizing regional-urban air quality models should throw more light on these results.

Secondly, the treatment of isoprene nitrates in the model, i.e., the assumed yield of isoprene oxidation by $\mathrm{NO}_{\mathrm{x}}$, and the assumption regarding the efficiency with which $\mathrm{NO}_{\mathrm{x}}$ is returned to the atmosphere (see Sect. 2.2 for details), will alter the sensitivity (magnitude/sign) of surface $\mathrm{O}_{3}$ to isoprene emissions presented here. As an extreme case to what is currently assumed in the model, if isoprene nitrates were assumed to be a terminal sink for $\mathrm{NO}_{\mathrm{x}}$, the increased natural isoprene emissions in the FC simulation, acting alone, would have likely resulted in a decrease in the surface $\mathrm{O}_{3}$ concentrations.

Finally, the predicted changes in future biogenic VOC emissions (e.g. isoprene) over specific geographical regions must also be regarded as somewhat uncertain. The first factor contributing to this uncertainty is the uncertainty in cloud cover changes (see Sect. 2.4). For example, in the FC sim- ulation, over the southeast and midatlantic United States, warmer temperatures and reduced cloud cover contributed to increased isoprene emissions. By contrast, we found that over the Mediterranean the cloud cover increased, resulting in a slight reduction in the isoprene emissions. The second factor contributing to this uncertainty is future vegetation changes, which we have not changed between the PC and FC simulations. It is worth noting here that, in addition to the uncertainties associated with future biogenic VOC emissions, there is notable uncertainty in the base isoprene emissions distribution itself (see Fiore et al., 2005, for a detailed analysis of this issue).

\section{Conclusions}

We have investigated the response of surface ozone to climate change over the eastern United States by performing and analyzing simulations corresponding to present (1990s) and future (2050s) climates using an integrated model of global climate, tropospheric gas-phase chemistry, and aerosols. Future climate is imposed using ocean boundary conditions corresponding to the IPCC SRES A2 scenario for the 2050s decade. The predicted climate change corresponds to an increase in the global annual-average surface air temperature by $1.7^{\circ} \mathrm{C}$, with a $1.4^{\circ} \mathrm{C}$ increase in the surface layer of the eastern United States. Present-day anthropogenic emissions and $\mathrm{CO}_{2} / \mathrm{CH}_{4}$ mixing ratios were used in both simulations while climate-sensitive natural emissions were allowed to vary with the simulated climate.

Our modeling results show that the severity and frequency of ozone episodes over the eastern United States increases due to future climate change, primarily as a result of increased ozone chemical production. The 95th percentile ozone mixing ratio increases by $5 \mathrm{ppbv}$ and the largest increase in the frequency occurs in the 80-90 ppbv range. The US EPA's current 8 -h ozone primary standard is $80 \mathrm{ppbv}$. The most substantial and statistically significant $(p<0.05)$ increases in episode frequency occur in the southeast and midatlantic United States. We examined the extent to which synoptic-scale circulation changes influenced the increased 
severity and frequency of ozone episodes by comparing the daily average sea level pressure anomaly distributions in several model grid cells for the present and future climate simulations. That analysis did not provide conclusive evidence pointing to systematic circulation changes and their role in the increased frequency of ozone episodes.

These results also suggest a lengthening of the ozone season over the eastern United States due to climate change to include late spring and early fall months, with increased ozone chemical production and shorter average ozone lifetime being two consistent features of the predicted seasonal response of surface ozone. The increased ozone chemical production in the future climate simulation is due to increases in: 1) natural isoprene emissions, which is largest over the southeast and midatlantic United States; 2) hydroperoxy radical concentrations resulting from increased water vapor concentrations; and, 3) $\mathrm{NO}_{\mathrm{x}}$ concentrations resulting from reduced PAN. The shorter ozone lifetime in the future climate simulation occurs through a combination of increases in the dry deposition removal rates, total chemical loss rates, and net transport, with increased dry deposition loss rates contributing most to the reduced lifetime in all seasons except summer.

Changes in natural isoprene emissions may have a significant effect on surface ozone levels over regions such as the southeast and midatlantic United States, where it increased annually by $20 \%$. Our sensitivity analysis shows that higher isoprene levels account for 50-60\% of the increased summertime ozone episodes in the future climate simulation for that region. The model predicted changes in surface ozone due to isoprene chemistry must be treated as somewhat uncertain, however, given the uncertanties associated with the treatment of isoprene nitrates, the base isoprene emissions inventory utilized, and future changes in the influencing meteorological factors such as cloud cover. Nevertheless, the remaining two factors causing increased surface ozone concentrations, i.e., increased water vapor concentrations and PAN-NO $\mathrm{N}_{\mathrm{x}}$ changes, are quite robust.

These results show that there is significant interannual variability in the frequency of ozone episodes. For example, we found that after 1 year $30-46 \%$ of the increase in the yearly frequency of ozone episodes could be attributed to interannual variability alone, which, after 5 years or more of simulation data, drops to $14-20 \%$. We conclude that it is necessary to utilize 5 years or more of simulation data in order to separate the effects of future climate change and interannual variability on ozone episodes in the eastern United States.

Acknowledgements. This work was supported by the NCER STAR Program, EPA (Agreement Number: RD-83096101-0). We would like to thank R. Healy at WHOI for his help.

Edited by: R. Cohen

\section{References}

Adams, P. J., Seinfeld, J. H., and Koch, D. M.: Global concentrations of tropospheric sulfate, nitrate, and ammonium aerosol simulated in a general circulation model, J. Geophys. Res., 104, 13 791-13 823, 1999.

Appenzeller, C., Holton, J. R., and Rosenlof, K. H.: Seasonal variation of mass transport across the tropopause, J. Geophys. Res., 101, 15 071-15 078, 1996.

Aw, J. and Kleeman, M. J.: Evaluating the first-order effect of intraannual temperature variability on urban air pollution, J. Geophys. Res., 108, 4365, doi:10.1029/2002JD002688, 2003.

Baertsch-Ritter, N., Keller, J., Dommen, J., and Prevot, A. S. H.: Effects of various meteorological conditions and spatial emission resolutions on the ozone concentration and $\mathrm{ROG} / \mathrm{NO}_{\mathrm{x}}$ limitation in the Milan area (I), Atmos. Chem. Phys., 4, 423-438, 2004, http://www.atmos-chem-phys.net/4/423/2004/.

Bey, I., Jacob, D. J., Yantosca, R. M., Logan, J. A., Field, B. D., Fiore, A. M., Li, Q. B., Liu, H. G. Y., Mickley, L. J., and Schultz, M. G.: Global modeling of tropospheric chemistry with assimilated meteorology: Model description and evaluation, J. Geophys. Res., 106, 23 073-23 095, 2001.

Brasseur, G., Kiehl, J., Schneider, T., Granier, C., Tie, X., and Hauglustaine, D.: Past and future changes in global tropospheric ozone: Impact on radiative forcing, Geophys. Res. Lett., 25, 3807-3810, 1998.

Cess, R. D., Potter, G. L., Blanchet, J. P., Boer, G. J., et al.: Intercomparison and interpretation of climate feedback processes in 19 atmospheric general-circulation models, J. Geophys. Res., 95, 16 601-16615, 1990.

Chung, S. H. and Seinfeld, J. H.: Global distribution and climate forcing of carbonaceous aerosols, J. Geophys. Res., 107, 4407, doi:10.1029/2001JD001397, 2002.

Collins, W. J., Derwent, R. G., Garnier, B., Johnson, C. E., Sanderson, M. G., and Stevenson, D. S.: Effect of stratospheretroposphere exchange on the future tropospheric ozone trend, J. Geophys. Res., 108, 8528, doi:10.1029/2002JD002617, 2003.

Dawson, J. P., Adams, P. J., and Pandis, S. N.: Sensitivity of ozone to summertime climate in the eastern USA: A modeling case study, Atmos. Environ., 41, 1494-1511, 2007.

Del Genio, A. D. and Yao, M. S.: Efficient cumulus parameterization for long-term climate studies: The GISS scheme, in: The Representation of Cumulus Convection in Numerical Models, Monogr. 46, edited by: Emanuel, K. A. and Raymond, D. J., Am. Meteorol. Soc., Boston, Mass., 181-184, 1993.

Del Genio, A. D., Yao, M. S., Kovari, W., and Lo, K. K. W.: A prognostic cloud water parameterization for global climate models, $\mathrm{J}$. Climate, 9, 270-304, 1996.

Fiore, A. M., Jacob, D. J., Bey, I., Yantosca, R. M., Field, B. D., Fusco, A. C., and Wilkinson, J. G.: Background ozone over the United States in summer: Origin, trend, and contribution to pollution episodes, J. Geophys. Res, 107(D15), doi: 10.1029/2001JD000982, 2002.

Fiore, A. M., Jacob, D. J., Mathur, R., and Martin, R. V.: Application of empirical orthogonal functions to evaluate ozone simulations with regional and global models, J. Geophys. Res., 108, D19 4431, doi:10.1029/2002JD003151, 2003.

Fiore, A. M., Horowitz, L. W., Purves, D. W., Levy, H., Evans, M. J., Wang, Y. X., Li, Q. B., and Yantosca, R. M.: Evaluating the contribution of changes in isoprene emissions to surface 
ozone trends over the eastern United States, J. Geophys. Res., 110, D12 303, doi:10.1029/2004JD005485, 2005.

Giacopelli, P., Ford, K., Espada, C., and Shepson, P.: Comparison of the measured and simulated isoprene nitrate distributions above a forest canopy, J. Geophys. Res., 110, D01 304, doi:10.1029/ 2004JD005123, 2005.

Goldstein, A., Fan, S., Goulden, M., Munger, J., and Wofsy, S.: Emissions of ethene, propene, and 1-butene by a midlatitude forest, J. Geophys. Res., 101, 9149-9158, 1996.

Guenther, A., Hewitt, C., Erickson, D., Fall, R., Geron, C., Graedel, T., Harley, P., Klinger, L., Lerdau, M., McKay, W., et al.: A global model of natural volatile organic compound emissions, J. Geophys. Res, 100, 8873-8892, 1995.

Hansen, J., Russell, G., Rind, D., Stone, P., Lacis, A., Lebedeff, S., Ruedy, R., and Travis, L.: Efficient 3-dimensional global-models for climate studies: MODEL-I and MODEL-II, Mon. Weather Rev., 111, 609-662, 1983.

Hauglustaine, D. A., Lathiere, J., Szopa, S., and Folberth, G. A.: Future tropospheric ozone simulated with a climate-chemistrybiosphere model, Geophys. Res. Lett., 32, L24 807, doi:10.1029/ 2005GL024031, 2005.

Hogrefe, C., Lynn, B., Civerolo, K., Ku, J. Y., Rosenthal, J., Rosenzweig, C., Goldberg, R., Gaffin, S., Knowlton, K., and Kinney, P. L.: Simulating changes in regional air pollution over the eastern United States due to changes in global and regional climate and emissions, J. Geophys. Res, 109, D22 301, doi:10.1029/2004JD004690, 2004.

Horowitz, L., Liang, J., Gardner, G., and Jacob, D.: Export of reactive nitrogen from North America during summertime- Sensitivity to hydrocarbon chemistry, J. Geophys. Res., 103, $13451-$ $13476,1998$.

Horowitz, L. W., Fiore, A. M., Milly, G. P., et al.: Observational constraints on the chemistry of isoprene nitrates over the eastern United States, J. Geophys. Res, 112, D12S08, doi: 10.1029/2006JD007747, 2007.

IPCC: Climate Change 2001: The Scientific Basis, Cambridge Univ. Press, New York.

Koch, D., Jacob, D., Tegen, I., Rind, D., and Chin, M.: Tropospheric sulfur simulation and sulfate direct radiative forcing in the Goddard Institute for Space Studies general circulation model, J. Geophys. Res., 104, 23 799-23 822, 1999.

Liao, H., Adams, P. J., Chung, S. H., Seinfeld, J. H., Mickley, L. J., and Jacob, D. J.: Interactions between tropospheric chemistry and aerosols in a unifiegeneral circulation model, J. Geophys. Res., 108, 4001, doi:10.1029/2001JD001260, 2003.

Liao, H., Seinfeld, J. H., Adams, P. J., and Mickley, L. J.: Global radiative forcing of coupled tropospheric ozone and aerosols in a unified general circulation model, J. Geophys. Res., 109, D24 204, doi:10.1029/2003JD004456, 2004.

Liao, H., Chen, W.-T., and Seinfeld, J. H.: Role of climate change in global predictions of future tropospheric ozone and aerosols, J. Geophys. Res., 111, D12 304, doi:10.1029/2005JD006852, 2006.

Logan, J. A.: An analysis of ozonesonde data for the lower stratosphere: Recommendations for testing models, J. Geophys. Res., 104, 16 151-16 170, 1999.
Mickley, L. J., Murti, P. P., Jacob, D. J., Logan, J. A., Koch, D. M., and Rind, D.: Radiative forcing from tropospheric ozone calculated with a unified chemistry-climate model, J. Geophys. Res., 104, 30 153-30 172, 1999.

Mickley, L. J., Jacob, D. J., and Field, B. D.: Effects of future climate change on regional air pollution episodes in the United States, Geophys. Res. Lett., 31, L24 103, doi:10.1029/ 2004GL021216, 2004.

Murazaki, K. and Hess, P.: How does climate change contribute to surface ozone change over the United States?, J. Geophys. Res., 111, D05 301, doi:10.1029/2005JD005873, 2006.

Racherla, P. N. and Adams, P. J.: Sensitivity of Global Tropospheric Ozone and Fine Particulate Matter Concentrations to Climate Change, J. Geophys. Res., 111, D24 103, doi:10.1029/ 2005JD006939, 2006.

Rind, D. and Lerner, J.: Use of on-line tracers as a diagnostic tool in general circulation model development. 1. Horizontal and vertical transport in the troposphere, J. Geophys. Res., 101, 12667 12 683, 1996.

Rind, D., Lerner, J., Shah, K., and Suozzo, R.: Use of on-line tracers as a diagnostic tool in general circulation model development 2. Transport between the troposphere and stratosphere, J. Geophys. Res., 104, 9151-9167, 1999.

Robertson, A., Overpeck, J., Rind, D., Mosley-Thompson, E., Zielinski, G., Lean, J., Koch, D., Penner, J., Tegen, I., and Healy, R.: Hypothesized climate forcing time series for the last 500 years, J. Geophys. Res., 106, 14 783-14 803, 2001.

Russell, G. L., Miller, J. R., and Rind, D.: A coupled atmosphereocean model for transient climate change studies, Atmos.-Ocean, 33, 683-730, 1995.

Seinfeld, J. H. and Pandis, S. N.: Atmospheric Chemistry and Physics: From Air Pollution to Climate Change, John Wiley, 3rd Ed., 1998.

Sillman, S. and Samson, F. J.: Impact of temperature on oxidant photochemistry in urban, polluted rural and remote environments, J. Geophys. Res., 100, 11 497-11 508, 1995.

Singh, H., OHara, D., Herlth, D., Sachse, W., Blake, D., Bradshaw, J., Kanakidou, M., and Crutzen, P.: Acetone in the atmosphere: Distribution, sources, and sinks, J. Geophys. Res, 99, 1805-1819, 1994.

Stevenson, D. S., Johnson, C. E., Collins, W. J., Derwent, R. G., and Edwards, J. M.: Future estimates of tropospheric ozone radiative forcing and methane turnoverthe impact of climate change, Geophys. Res. Lett., 27, 2073-2076, 2000.

Wang, Y. H., Jacob, D. J., and Logan, J. A.: Global simulation of tropospheric $\mathrm{O}_{3}-\mathrm{NO}_{\mathrm{x}}$-hydrocarbon chemistry 1 . Model formulation, J. Geophys. Res, 103, 10713-10 725, 1998.

Wesely, M. L.: Parameterization of surface resistances to gaseous dry deposition in regional-scale numerical-models, Atmos. Environ., 23, 1293-1304, 1989.

Zeng, G. and Pyle, J. A.: Changes in tropospheric ozone between 2000 and 2100 modeled in a chemistry-climate model, Geophys. Res. Lett., 30, 1392, doi:10.1029/2002GL016708, 2003. 